\title{
Problem Based Learning to Improve Critical Thinking
}

\section{Egi Gustomo Arifin}

\author{
SD Negeri Tegalsari \\ egi.g.arifin@gmail.com
}

\section{Article History}

received 3/12/2020

\begin{abstract}
Based on the 2013 curriculum, learning in the implementation of the curriculum has also changed, namely with a scientific approach. The criteria in this approach emphasize several aspects, including learning materials based on facts or phenomena that can be explained by logic, teacher explanations, student responses, and educative interactions between teachers and students, subjective thinking, encouraging and inspiring students to think critically, analytically, and accurately in identifying, understanding, solving problems, and applying learning materials. Teachers as educators must develop student's critical thinking skills. Aim of this study describes the concept of Problem Based Learning (PBL), components of critical thinking skills and the relationship of PBL with critical thinking skills. The results are problem-based learning can improve critical thinking through 5 phases, (a) orienting problems; (b) organize students to research; (c) assist group investigations; (d) develop and present the work; (e) analyze and evaluate the problem solving process.
\end{abstract}

Keywords: 2013 curriculum, critical thinking, problem based learning

\begin{abstract}
Abstrak
Berdasarkan kurikulum 2013, pembelajaran dalam pelaksanaan kurikulum juga mengalami perubahan yaitu dengan pendekatan saintifik. Kriteria dalam pendekatan ini menekankan pada beberapa aspek, antara lain materi pembelajaran berdasarkan fakta atau fenomena yang dapat dijelaskan dengan logika, penjelasan guru, respon siswa, dan interaksi edukatif antara guru dan siswa, berpikir subjektif, mendorong dan menginspirasi siswa untuk berpikir kritis, analitis, dan akurat dalam mengidentifikasi, memahami, memecahkan masalah, dan menerapkan materi pembelajaran. Guru sebagai pendidik harus mengembangkan kemampuan berpikir kritis siswa. Tujuan penelitian ini mendeskripsikan konsep Problem Based Learning (PBL), komponen keterampilan berpikir kritis dan hubungan PBL dengan keterampilan berpikir kritis. Hasilnya adalah pembelajaran berbasis masalah dapat meningkatkan berpikir kritis melalui 5 fase, (a) mengorientasikan masalah; (b) mengorganisasi siswa untuk meneliti; (c) membantu investigasi mandiri dan berkelompok; (d) mengembangkan dan mempresentasikan karya; (e) menganalisis dan mengevaluasi proses pemecahan masalah.
\end{abstract}

Kata kunci: Kurikulum 2013, berpikir kritis, problem based learning

Social, Humanities, and Education Studies (SHEs): Conference Series https://jurnal.uns.ac.id/shes 


\section{PENDAHULUAN}

Berdasarkan pola kurikulum 2013, maka pembelajaran dalam implementasi kurikulum tersebut juga mengalami perubahan yakni dengan pendekatan saintifik atau pendekatan ilmiah. Kriteria dalam pendekatan ini menekankan beberapa aspek antara lain materi pembelajaran berbasis pada fakta atau fenomena yang dapat dijelaskan dengan logika, penjelasan guru, respon siswa, dan interaksi edukatif guru dan siswa, pemikiran subjektif, mendorong dan menginspirasi siswa berfikir secara kritis, analistis, dan tepat dalam mengidentifikasi, memahami, memecahkan masalah, dan mengaplikasikan materi pembelajaran, mendorong dan menginspirasi siswa mampu berfikir hipotetik dalam melihat perbedaan, kesamaan, dan tautan satu sama lain dari materi pembelajaran, mendorong dan menginspirasi siswa, mampu memahami, menerapkan, dan mengembangkan pola berfikir yang rasional dan objektif, berbasis pada konsep, teori, dan fakta empiris yang dapat dipertanggungjawabkan.

Untuk mencapai kualitas yang telah dirancang dalam dokumen kurikulum tersebut, kegiatan pembelajaran perlu menggunakan prinsip. Pertama, berpusat pada peserta didik. Kedua, mengembangkan kreativitas peserta didik. Ketiga, menciptakan kondisi menyenangkan dan menantang. Keempat, bermuatan nilai, estetika, etika, logika, dan kinestetika. Dan kelima menyediakan pengalaman belajar yang beragam melalui penerapan berbagai strategi dan metode pembelajaran yang menyenangkan, kontekstual, efektif, efisien, dan bermakna. Untuk mengantarkan agar peserta didik memiliki kompetensi tersebut diperlukan suatu kegiatan pembelajaran yang dapat memunculkan sikap-sikap tersebut di atas. Salah satu pembelajaran yang dapat diterapkan adalah pembelajaran yang menggunakan model pembelajaran berbasis masalah (Problem Based Learning). Hal ini didukung oleh pendapat Savery dan Duffy (1995) (dalam Pecore, 2013: 9) yang menyatakan bahwa PBL ini adalah salah satu contoh terbaik dalam mengembangkan pembelajaran konstruktivisme

Pembelajaran yang utama yang seharusnya dilakukan setiap mata pelajaran di sekolah menurut John Dewey (Abidin, 2014: 158) adalah pembelajaran yang merangsang pikiran peserta didik untuk memperoleh segala kemampuan belajar yang bersifat nonskolastik. Upaya efektif yang sesuai dengan pernyataan di atas adalah dengan menerapkan model pembelajaran konstruktivisme yang tidak bersifat teacher centered tetapi bersifat student centered.

Pembelajaran berbasis masalah merupakan suatu metode pembelajaran yang menantang peserta didik untuk "belajar bagaimana belajar", bekerja secara berkelompok untuk mencari solusi dari permasalahan dunia nyata. Masalah yang diberikan ini digunakan untuk mengikat peserta didik pada rasa ingin tahu pada pembelajaran yang dimaksud. Masalah diberikan kepada peserta didik, sebelum peserta didik mempelajari konsep atau materi yang berkenaan dengan masalah yang baru dipecahkan.

Bukti empirik yang mendukung model PBL dalam meningkatkan berpikir kritis adalah hasil penelitian yang telah dilakukan Tosun dan Taskesenligil (2011: 129), yang menunjukan bahwa PBL memiliki kontribusi yang positif terhadap kemampuan berpikir kritis yang merupakan bagian dari sub dimensi kognitif namun belum melihat bagaimana pengaruhnya terhadap penguasaan konsep secara bersamaan. Kemudian dalam penelitian yang dilakukan Akinoglu \& Tandogen (2007) menunjukan bahwa PBL berpengaruh pada pencapaian prestasi, sikap, dan konsep belajar siswa sekolah lanjutan dengan materi energi.

Menurut Polya (dalam Amir, 2009: 45) kemampuan pemecahan masalah adalah "proses yang ditempuh oleh seseorang untuk menyelesaikan masalah yang dihadapinya sampai masalah itu tidak lagi menjadi masalah baginya". Sedangkan menurut Gagne (dalam Amir, 2009: 45) kemampuan pemecahan masalah merupakan "seperangkat prosedur atau strategi yang memungkinkan seseorang dapat meningkatkkan kemandirian dalam berpikir". 
Dari kedua pendapat tersebut dapat disimpulkan bahwa kemampuan pemecahan masalah merupakan kecakapan atau potensi yang dimiliki siswa dalam menyelesaikan permasalahan dan mengaplikasikan dalam kehidupan sehari-hari. PBL memiliki kelebihan dan kelemahan. Kelebihan dan kelemahan tersebut disajikan sebagai berikut. Menurut Amir (2009: 27), penerapan model Problem Based Learning memiliki beberapa kelebihan, diantaranya 1) fokus kebermaknaan, bukan fakta (deep versus surface learning), 2) meningkatkan kemampuan siswa untuk berinisiatif, 3) pengembangan keterampilan dan pengetahuan, 4) pengembangan keterampilan interpersonal dan dinamika kelompok, 5) pengembangan sikap self-motivated, 6) tumbuhnya hubungan siswa-fasilitator, 7) jenjang penyampaian pembelajaran dapat ditingkatkan. Di samping memiliki kekuatan, menurut Nurhadi (2004: 110) model Problem Based Learning juga memiliki beberapa kelemahan, antara lain 1) pencapaian akademik dari individu siswa, 2) waktu yang diperlukan untuk implementasi, 3) perubahan peran siswa dalam proses, 4) perubahan peran guru dalam proses, dan 5) perumusan masalah yang baik.

Sebagai suatu kemampuan yang dimiliki oleh siswa dalam memecahkan suatu masalah, perlu ada beberapa indikator-indikator dari kemampuan pemecahan masalah. Indikator-indikator kemampuan pemecahan masalah menurut Amir (2009: 24) adalah 1) mampu mengklarifikasi istilah konsep yang belum jelas, 2) mampu merumuskan masalah dan menganalisis masalah, 3) mampu menata gagasan secara sistematis dan menganalisisnnya dengan dalam, dan 4) mampu mencari informasi tambahan dari sumber lain.

Berdasarkan uraian di atas rumusan penelitian ini yaitu: (1) Bagaimana konsep model pembelajaran Problem Based Learning ( $\mathrm{PBL})$ ? (2) Bagaimana komponen keterampilan berpikir kritis? (3) Bagaimana hubungan model pembelajaran Problem Based Learning (PBL) dengan keterampilan berpikir kritis?

\section{A. Konsep Problem Based Learning (PBL)}

\section{HASIL DAN PEMBAHASAN}

Problem Based Learning atau dikenal dengan istilah pembelajaran berbasis masalah sebagai salah satu model pembelajaran yang diterapkan dalam kurikulum 2013. Margetson (dalam Rusman, 2011) menyebutkan bahwa Problem Based Learning sebagai model pembelajaran yang dapat membantu siswa untuk meningkatkan perkembangan keterampilan belajar sepanjang hayat dalam pola pikir yang terbuka, reflektif, kritis, dan belajar aktif, serta memfasilitasi keberhasilan memecahkan masalah, komunikasi, kerja kelompok, dan keterampilan interpersonal dengan lebih baik dibanding model lain.

Pembelajaran berbasis masalah atau PBL adalah pembelajaran yang menitik beratkan kepada peserta didik sebagai pembelajar serta terhadap permasalahan yang otentik atau relevan yang akan dipecahkan dengan menggunakan seluruh pengetahuan yang dimilikinya atau dari sumber-sumber lainnya (Lidinillah, 2013). Ciri-ciri pembelajaran Problem Based Learning (PBL) yaitu menerapkan pembelajaran yang kontekstual, masalah yang disajikan dapat memotivasi siswa peserta didik untuk belajar, pembelajaran integritas yaitu pembelajaran termotivasi dengan masalah yang tidak terbatas, peserta didik terlibat secara aktif dalam pembelajaran, kolaborasi kerja, peserta didik memiliki berbagai keterampilan, pengalaman, dan berbagai konsep. Pembelajaran Problem Based Learning menjadikan masalah autentik sebagai fokus pembelajaran yang bertujuan agar siswa mampu menyelesaikan masalah tersebut, sehingga siswa terlatih untuk berpikir kritis dan berpikir tingkat tinggi.

Aris Shoimin (2014: 131) mengemukakan bahwa langkah-langkah dalam model pembelajaran Problem Based Learning adalah sebagai berikut:

a. Guru menjelaskan tujuan pembelajaran. Menjelaskan logistik yang dibutuhkan. Memotivasi siswa terlibat dalam aktivitas pemecahan masalah yang dipilih. 
b. Guru membantu siswa mendefinisikan dan mengorganisasikan tugas belajar yang berhubungan dengan masalah tersebut (menetapkan topik, tugas, jadwal, dll).

c. Guru mendorong siswa untuk mengumpulkan informasi yang sesuai, eksperimen untuk mendapatkan penjelasan dan pemecahan masalah, pengumpulan data, hipotesis, dan pemecahan masalah.

d. Guru membantu siswa dalam merencanakan serta menyiapkan karya yang sesuai seperti laporan dan membantu mereka berbagai tugas dengan temannya.

e. Guru membantu siswa untuk melakukan refleksi atau evaluasi terhadap penyelidikan mereka dan proses-proses yang mereka gunakan.

Sedangkan menurut Arends (2008: 55), langkah-langkah dalam melaksanakan PBL ada 5 fase yaitu (1) mengorientasi siswa pada masalah; (2) mengorganisasi siswa untuk meneliti; (3) membantu investigasi mandiri dan berkelompok; (4) mengembangkan dan menyajikan hasil karya; (5) menganalisis dan Permasalahan yang digunakan dalam PBL adalah permasalahan yang dihadapi di dunia nyata. Meskipun kemampuan individual dituntut bagi setiap siswa, tetapi dalam proses belajar dalam PBL siswa belajar dalam kelompok untuk memahami persoalan yang dihadapi. Kemudian siswa belajar secara individu untuk memperoleh informasi tambahan yang berhubungan dengan pemecahan masalah. Peran guru dalam PBL yaitu sebagai fasilitator dalam proses pembelajaran.

\section{B. Konsep Berpikir Kritis}

Critical thinking adalah salah satu kecakapan yang diharapkan terbentuk pada diri peserta didik. Critical thinking menurut Beyer (Kemendikbud, 2017: 6) adalah: (1) mengukur kualitas dari suatu sumber, (2) mampu menentukan antara yang relevan dan yang tidak relevan, (3) membedakan fakta dari penilaian, (4) mengidentifikasi dan mengevaluasi pendapat yang tidak terucapkan, (5) mengidentifikasi kesalahan atau bias yang ada, (6) mengidentifikasi sudut pandang, dan (7) mengevaluasi bukti yang didapatkan untuk mendukung pendapat.

Critical thinking adalah proses yang rumit, dan jika dilakukan dengan benar akan membantu dalam menilai ide-ide kompleks secara sistematis, sehingga masalahnya lebih mudah dipecahkan. Kecakapan critical thinking menggunakan pemikiran dasar menganalisis argumen dan membawa wawasan peserta didik pada setiap interpretasi, untuk meningkatkan pola penalaran yang kohesif dan koheren, merumuskan masalah, dengan melakukan deduksi dan induksi, serta menentukan keputusan yang tepat. Dengan demikian kecakapan critical thinking adalah kecakapan berpikir tingkat tinggi (Nuraida, 2016: 1).

Aspek-aspek kecakapan critical thinking menurut Carin \& Sund (Devi, 2017: 53) mencakup keterampilan berpikir untuk: mengklasifikasi, membuat asumsi, memprediksi dan berhipotesis, menyimpulkan dan menginterprestasikan data serta menarik kesimpulan, mengukur, merancang penyelidikan untuk memecahkan suatu masalah, mengamati, mereduksi kesalahan eksperimen, mengevaluasi, dan menganalisis.

Langkah-langkah berpikir kritis menurut Zubaidah (2016: 10) dikelompokkan menjadi tiga langkah yaitu: pengenalan masalah-masalah (defining/clarifiying problems), menilai informasi dan pemecahan masalah/penarikan kesimpulan (solving problems/ drawing conclusion). Langkah-langkah ini juga diperlukan kecakapan yang dinamai 12 kecakapan esensial dalam berpikir kritis (twelve essential critical thinking skills), sebagai berikut:

1) Mengenali masalah (defining and clarifying problem)

a) Mengidentifikasi isu-isu atau permasalahan pokok.

b) Membandingkan kesamaan dan perbedaaan-perbedaan.

c) Memilih informasi yang relevan.

d) Merumuskan/ memformulasi masalah.

2) Menilai informasi yang relevan 
a) Menyeleksi fakta, opini, hasil nalar/judgment.

b) Mengecek konsistensi.

c) Mengidentifikasi asumsi

d) Mengenali kemungkinan faktor stereotip.

e) Mengenali kemungkinan bias, emosi, propaganda, salah penafsiran kalimat.

f) Mengenali kemungkinan perbedaan orienasi nilai dan ideologi.

3) Pemecahan masalah/penarikan kesimpulan (solving problems/drawing conclusion)

a) Mengenali data-data yang diperlukan dan cukup tidaknya data.

b) Meramalkan konsekuensi yang mungkin terjadi dari keputusan/ pemecahan masalah/ kesimpulan yang diambil.

\section{Hubungan PBL dengan Berpikir Kritis}

PBL merupakan pembelajaran yang memfasilitasi peserta didik belajar melalui pemecahan masalah dunia nyata dan autentik serta mengintegrasikan pengetahuan lintas disiplin (Keziah, 2010). Wahyudi (2015) menambahkan bahwa PBL mampu meningkatkan keterampilan proses sains dan hasil belajar peserta didik dibandingkan model konvensional. Istanti (2015) menjelaskan bahwa PBL mampu meningkatkan motivasi belajar peserta didik.

Menurut Moore \& Stanley (2010:10) "in Bloom's Taxonomy, the three levels that require higher-level thinking are analysis, synthesis, and evaluation". Kecakapan critical thinking membutuhkan pengajaran dan praktek yang dapat meningkatkan kecakapan critical thinking peserta didik dengan (1) menggunakan strategi pembelajaran yang mendorong peserta didik terlibat dalam proses pembelajaran, sehingga pembelajaran tidak hanya berpusat pada guru (teacher center), (2) memfokuskan pembelajaran pada kegiatan pembelajaran daripada materi, dan (3) menggunakan teknik penilaian dengan memberikan tanggapan critical thinking peserta didik (Snyder \& Snyder, 2008: 90).

Berdasarkan uraian di atas dapat disimpulkan bahwa PBL erat kaitannya dengan berpikir kritis. Dalam PBL siswa disajikan masalah yang akan dijadikan fokus utama pembelajaran. Siswa dikenalkan cara belajar dan bekerjasama dalam kelompok untuk menyelesaikan masalah-masalah dalam dunia nyata. Kegiatan tersebut akan melatih siswa berpikir kritis sesuai dengan aspek-aspek kecakapan critical thinking menurut Carin \& Sund (Devi, 2017: 53) yang mencakup keterampilan berpikir untuk: mengklasifikasi, membuat asumsi, memprediksi dan berhipotesis, menyimpulkan dan menginterprestasikan data serta menarik kesimpulan, mengukur, merancang penyelidikan untuk memecahkan suatu masalah, mengamati, mereduksi kesalahan eksperimen, mengevaluasi, dan menganalisis. Berpikir kritis adalah keterampilan yang diperlukan pada abad 21 ini. Sehingga PBL dapat dijadikan salah satu model pembelajaran untuk menghadapi tantangan abad 21.

\section{SIMPULAN}

Sesuai dengan rumusan masalah dan pembahasan, dapat diambil simpulan bahwa (1) PBL merupakan metode pembelajaran berbasis masalah yang dapat menanamkan berpikir kritis pada siswa Sekolah Dasar melalui 5 fase yaitu (a) mengorientasi siswa pada masalah; (b) mengorganisasi siswa untuk meneliti; (c) membantu investigasi mandiri dan berkelompok; (d) mengembangkan dan menyajikan hasil karya; (e) menganalisis dan mengevaluasi proses pemecahan masalah. (2) Berpikir kritis adalah kemampuan berpikir logis pada siswa untuk memecahkan masalah dari berbagai sudut pandang. (3) Berpikir kritis dapat ditanamkan pada siswa melalui metode pembelajaran Problem Based Learning (PBL). 
DAFTAR PUSTAKA

Abidin, Yunus. (2014). Desain Sistem Pembelajaran Dalam Konteks Kurikulum 2013. Bandung: PT Refika Aditama.

Akcay, B. (2009). Problem-Based Learning in Science Education. Journal of Turkish Science Education (JSE), 6 (1), 26-27.

Akinoglu, O. dan R.O. Tandogan. (2007). The Effect of Problem Based Active Learning of Student's Academic Achievement, Attitude and Concept Learning. Eurasia Journal of Mathemathics, science \& Technology Education, 3 (1), 71-81.

Amir, Taufiq. (2009). Inovasi Pendidikan Melalui Problem Based Learning. Jakarta: Kencana Prenada Media Group.

Arends, L. Richard. (2008). Learning to Teach. Yogyakarta: Pustaka Pelajar

Devi, Rizqa A. (2017). Pengaruh Model Project-Based Learning Terhadap Kreativitas dan Berpikir Kritis Peserta Didik pada Materi Sistem Respirasi Di SMA N 1 Temanggung, Tesis. Universitas Negeri Yogyakarta, Yogyakarta, Indonesia.

Ennis, Robert H. (1993). Critical thinking assesment. Theory Into Practice, (32) 3, 179186.

Facione, Peter A. (2011). Critical Thinking: What It Is and Why It Counts. California: The California Academic Press.

Gambrill, E \& Gibbs, L. (2009). Critical Thinking for Helping Professionals Skills Based Workbook ( $3^{\text {rd }}$ Ed.). New York: Oxford University Press

Halpern, Diane F. (2014). Thought and Knowledge: An Introduction to Critical Thinking (5th Edition). New York: Psychology Press.

Hooks, Bell. (2010). Teaching Critical Thinking: Practical Wisdom. New York: Routledge

Istanti, R. (2015). Pengaruh Model Problem Based Learning (PBL) Terhadap Motivasi Belajar Siswa Kelas V SD Negeri Gadingan. Jurnal Pendidikan Guru Sekolah Dasar, 4 (12), 1-8.

Kemendikbud. (2017). Panduan Penilaian oleh Pendidik dan Satuan Pendidikan untuk Sekolah Menengah Atas. Jakarta: Direktorat Jenderal Pendidikan Dasar dan Menengah

Keziah, A. (2010). A Comparative Study of Problem-Based and Lecture Based Learning in Secondary School Students'motivation to Learn Science. International Journal of Science and Technology Education Research, 1 (6), 126-131.

Kuswana, W. S. (2013). Taksonomi Berpikir. Bandung: PT Remaja Rosdakarya Offset.

$\mathrm{Li}$, Zhanfang \& Chunhong Yang. (2014). Reading to Writen: A Practice of Critical Thinking. Journal of Art and Humanities, 3 (5).

Lidinillah, D. A. M. (2008). "Strategi Pembelajaran Pemecahan Masalah di Sekolah Dasar". Jurnal Pendidikan Dasar, 1 (10), 67-77.

Moore, Betsy \& Stanley, Todd. (2010). Critical Thinking and Formative Assesment: Increasing the Rigor in Your Classroom. Larchmont: Eye on Education Inc.

Mugla. (2011). Overviews on Inquiry Based and Problem Based Learning Methods. Journal of Education Scince: ISSN 1308-8971.

Muhson, Ali. (2009). Peningkatan Minat Belajar dan Pemahaman Mahasiswa Melalui Penerapan Problem-Based Learning. Jurnal Kependidikan, 39 (2), 171-182.

Nhat, Ho Thi dkk. (2018). The Development of Critical Thinking of Students in Vietnamese Schools: From Policies To Practices. American Journal of Education Research, (6) 5, 431-435.

Nuraida, D. (2016). Critical Thinking Skill and Its Correlation with Student Achievement Index Cumulative. Proceeding of $3^{\text {th }}$ International Conference on Research, Implementation and Education of Mathematics and Science, BE-02 (hlm. 7-11). Yogyakarta.

Nurhadi dkk. (2004). Pembelajaran Kontekstual dan penerapannya dalam KBK. Malang: UM Press 